\title{
Relationships among Attitudes, Coping Strategies, and Achievement in Doctoral-Level Statistics Courses: A Mixed Research Study
}

\author{
Julie P. Combs and Anthony J. Onwuegbuzie \\ Department of Educational Leadership and Counseling, \\ Sam Houston State University, Huntsville, Texas, USA
}

jc@evalresearch.com tonyonwuegbuzie@aol.com

\begin{abstract}
Because of the important role that attitudes toward statistics and motivation have played in statistics courses, Ramirez, Emmioglu, and Schau (2010) recently conceptualized that Eccles and Wigfield's (2002) Expectancy-Value Model (EVM) is applicable for students enrolled in statistics courses. However, to date, the applicability of the EVM for understanding students' attitudes toward statistics has not been tested empirically. Thus, the purpose of this mixed research study was twofold: (a) to build on Ramirez et al.'s (2010) conceptualization by testing the EVM as a viable framework for understanding the statistics learning context; and (b) to examine the role that coping strategies play within the EVM framework by exploring interrelationships among attitudes, coping strategies, and statistics achievement. A qualitative-dominant mixed research design was used. Specifically, 18 doctoral students who had recently taken a statistics class participated in three in-depth focus groups. The ensuing qualitative data were supplemented by quantitative data via scores from a measure of coping strategies used in statistics courses that was administered to all participants. The qualitative and quantitative data provided strong support for the EVM. Moreover, the emergence of five coping strategies themes suggested the appropriateness of expanding the EVM to a more solution-focused model, namely, the Expectancy-Value Coping Strategies (EVCS) model, wherein coping strategies mediate the relationship between statistics attitudes and statistics achievement.
\end{abstract}

Key Words: statistics, statistics courses, attitudes toward statistics, statistics learning, statistics, achievement, coping strategies

\section{Introduction}

The majority of doctoral students representing the social and behavioral sciences, including the field of education, are required to take at least one statistics course as part of their degree programs (Capraro \& Thompson, 2008; Leech \& Goodwin, 2008). Unfortunately, the statistics

Material published as part of this publication, either on-line or in print, is copyrighted by the Informing Science Institute. Permission to make digital or paper copy of part or all of these works for personal or classroom use is granted without fee provided that the copies are not made or distributed for profit or commercial advantage AND that copies 1) bear this notice in full and 2) give the full citation on the first page. It is permissible to abstract these works so long as credit is given. To copy in all other cases or to republish or to post on a server or to redistribute to lists requires specific permission and payment of a fee. Contact Publisher@InformingScience.org to request redistribution permission. course can be a negative experience for many graduate students (Onwuegbuzie, DaRos, \& Ryan, 1997; Onwuegbuzie \& Wilson, 2003). Further, students enrolled in statistics courses typically experience lower levels of performance in statistics courses than in all other courses taken in their degree programs (e.g., Onwuegbuzie, 2000; Onwuegbuzie \& Seaman, 1995). 
Because of the widespread underachievement in statistics courses worldwide, since the early 1970s (i.e., Fisch, 1971) researchers have "studied different avenues to understand what occurs with students so steps can be taken to improve learning as well as satisfaction in college statistics courses" (Perepiczka, Chandler, \& Becerra, 2011, p. 99). Over the 40-year history of statistics achievement research, researchers have identified an array of cognitive and non-cognitive predictors of both performance and achievement. In particular, motivation has been found to play an important role in students' ability to learn statistics (e.g., Bandalos, Finney, \& Geske, 2003). However, indubitably, the most important construct in the statistics learning context that has emerged has been students' attitudes toward statistics. Indeed, the popularization of this construct prompted Schau (2003) to deem attitudes toward statistics as being the "other important outcome in statistics education" (p. 5). Attitudes toward statistics represent a multidimensional construct referring to "distinct, but related dispositions pertaining to favourable and unfavourable responses with regard to statistics and statistics leaning" (Vanhoof, Kuppens, Castro Sotos, Verschaffel, \& Onghena, 2011, p. 35). More specifically, the construct of attitudes toward statistics consists of cognitive (representing mental processes of perception, memory, judgment, reasoning, beliefs, and knowledge about the ability required to learn statistics), affective (representing emotions, feeling, and motivation related to statistics classes and assessments), and behavioral (representing observed activities and action tendencies in studying and performance in statistics examinations and other assessments) components (Schau, Stevens, Dauphinee, \& DelVecchio, 1995).

Because of the important role that attitudes toward statistics and motivation have played in statistics courses, Ramirez, Emmioglu, and Schau (2010) recently posited in their seminal article that Eccles and Wigfield's (2002) Expectancy-Value Model (EVM) is applicable for students enrolled in statistics courses. Ramirez et al.'s (2010) re-conceptualization is directly applicable to the present study, which is an examination of the statistics learning context. According to Eccles and Wigfield (2002), students' Expectations for Success and Subjective Task Value (STV) predict their achievement outcomes. Also, students are more apt to decide to perform tasks (e.g., enrolling in and completing courses, graduating from their degree programs) that they value and in which they expect to perform well. The STV comprises the following four elements: Attainment Value (i.e., how important a student deems the task), Intrinsic Value (i.e., the student's level of interest in or satisfaction/enjoyment from engaging in the task), Utility Value (i.e., how the utility of the task relates to the student's future goals, such as a career), and Cost (i.e., the possible reasons for a student attempting to avoid performing the task such as fear of failure, task difficulty, or situational anxiety). Further, Expectations for Success are positively influenced by high Attainment, Interest, and Utility Values and negatively influenced by high Cost and vice versa. Additionally, the EVM includes other factors, such as Stable Child Characteristics and Previous Achievement-Related Experiences.

Using the widely administered measure of statistics attitudes, namely, the Survey of Attitudes Toward Statistics (SATSC), Ramirez et al. (2010, p. 835) reframed the EVM by mapping the six attitude components of the SATSC onto to EVM, as follows: (a) the component Affect represents the EVM constructs "Affective Reactions" and Enjoyment Value"; (b) the component Cognitive Competence represents the EVM constructs "Self-concept of One's Abilities" and "Expectation of Success"; (c) the component Value represents the EVM constructs "Attainment Value" and "Utility Value"; (d) the component Difficulty represents the EVM construct "Perception of.... "Task Demands"; (e) the component Interest represents the EVM construct "Intrinsic Value"; and (f) the component Effort represents the EVM construct "Cost." In addition, the Student Characteristics items represent the EVM construct "Stable Child Characteristics" and the Previous Achievement items represent the EVM construct "Previous Achievement-Related Experiences" and "Interpretations of Experience." 
However, as noted by Ramirez et al. (2010), to date the applicability of the EVM for understanding students' attitudes toward statistics has not been tested empirically - which is not surprising bearing in mind the recency of Ramirez et al.'s conceptualization. This was the overall goal of the present study. Specifically, the first purpose of this study was to use primarily qualitative techniques - within a mixed research framework - to build on Ramirez et al.'s excellent work by testing the EVM as a viable framework for understanding the statistics learning context.

The EVM, if found to be a viable model for understanding the statistics learning context, will represent a useful tool for determining pathways for explicating how statistics attitudes serve as antecedents of statistics achievement. However, in such a case, the EVM would represent what we call a problem-focused model, helping to identify the statistical learning and statistical literacy difficulties that students face vis-à-vis statistics attitudes. Thus, the logical appeal of the EVM would be enhanced further if the EVM would include one or more elements that mediate the relationship between statistics attitudes and achievement in statistics courses. The addition of mediating variables would transform the EVM from a problem-focused model to a solution-focused model.

One such potential mediating variable is coping strategies. Indeed, coping strategies are the specific tactics that students may use to alleviate stress when demands in their environments exceed their resources to manage such demands (Lazarus \& Folkman, 1984). Specific to the statistics course, Jarrell and Burry (1989) identified two coping strategies used by college students: study coping strategies and examination-taking coping strategies. Students with poor study coping strategies experience problems when learning or reviewing content (Tobias, 1980) and are easily distracted during study times (Dusek, 1980). Students with poor examination-taking coping strategies have trouble during the testing period (Onwuegbuzie \& Daley, 1996). As such, students with more positive coping strategies in both arenas tend to fare better on examinations (Tobias, 1985) and remain less anxious (Onwuegbuzie \& Daley, 1996) than do students with poorer coping strategies. The repeated finding of a link between statistics attitudes and statistics achievement makes it important for researchers to identify factors that mediate the relationship between statistics anxiety and course performance. Therefore, a second purpose was to examine the role that coping strategies play within the EVM framework by exploring interrelationships among attitudes, coping strategies, and statistics achievement.

With very few exceptions (e.g., DeVaney, 2010; Suanpang, Petocz, \& Kalceff, 2004; Xu, Meyer, $\&$ Morgan, 2009), the vast majority of studies in the area of statistics attitudes have involved the use of quantitative techniques. Indeed, as very recently concluded by Perepiczka et al. (2011), "qualitative studies need to be conducted to better capture students' experiences in statistics classes" (p. 106). Interestingly, traditionally, quantitative methods typically are used to test hypothesized models. However, as noted by Onwuegbuzie and Teddlie (2003), qualitative data-analytic methods - specifically, confirmatory thematic analyses - can be used to test an extant theory (i.e., theory driven), when appropriate. Even more importantly, by using qualitative techniques, unlike virtually every study conducted to date in the area of attitudes toward statistics, we were able to obtain the voices of doctoral students rather than obtain only quantitative measures. These voices, in turn, would enable us to document the students' lived experience while enrolled in statistics courses. Further, by collecting focus group data rather than individual interview data, we were able to "capitaliz(e) on the interaction that occurs within the group setting" (Sim \& Snell, 1996, p. 189). Other advantages of using focus groups in our study included the following: (a) they represented a socially oriented method of collecting data within a social environment, namely an academic setting (Krueger, 2000); (b) they provided information in the context of the interaction that occurred among the doctoral student participants (Morgan, 1988); (c) they had the potential to yield a greater amount of spontaneity in responses compared with individual interviews (Butler, 1996); (d) they provided a safe venue for answering our research questions (Vaughn, Schumm, 
\& Sinagub, 1996); (e) they had the potential to empower the participants as a result of a feeling of group membership and cohesiveness (Peters, 1993); and (f) they provided an opportunity for participants to identify personal problems in the statistics course and to discuss possible solutions (Duggleby, 2005).

\section{Method}

\section{Participants}

Students in this study were members of three cohorts representing a doctorate of education program in the department of Educational Leadership. The doctorate of education was one of five doctoral programs at a comprehensive research university with a total student enrolment of approximately 18,000 . Other programs offering a doctorate degree were reading, criminal justice, psychology, and counseling. These students represented approximately 80 active students. On average, $50 \%$ of the students completed their degrees in 3.5 years. Overall, about $95 \%$ of the students enrolled in this program completed their degrees in 6 years.

Participants consisted of 18 doctoral students in the disciplines of educational leadership or reading at a university located in the southern United States. Students who had taken a doctoral-level statistics course within the past 6 months at the time of the study were invited to participate. Of the 20 students invited, 18 agreed. Of the 18 participants, 11 were women $(61.1 \%)$. With respect to their ages, one (5.6\%) was in her/his $50 \mathrm{~s}, 10(55.6 \%)$ were in their $40 \mathrm{~s}$, five $(27.8 \%)$ were in their 30s, and two $(11.1 \%)$ were in their $20 \mathrm{~s}$. The racial composition was as follows: 13 were White $(72.2 \%)$, one $(5.6 \%)$ was African American, and four $(22.2 \%)$ were Hispanic. All but one of the sample members were employed as teachers $(n=9)$ in public schools or colleges or school administrators $(n=8)$. Seven participants worked in elementary schools, with five individuals being employed at the college or university levels. The remaining participants worked in middle schools, high schools, or central administration. The participants' service in education ranged from 7 years to 33 years $(M=15.7, S D=6.74)$. In regards to the research- or mathematics-based courses taken, the participants had completed a mean of 3.94 college-level mathematics courses $(S D=4.29), 3.78$ research courses $(S D=2.02)$, and 2.11 statistics courses $(S D=1.64)$.

\section{Sampling Design}

Because the participants contributed both qualitative and quantitative data at the same time point, the mixed research sampling design used was a Concurrent Design using Identical Samples (Onwuegbuzie \& Collins, 2007), which has been found to be the most common sampling design in mixed research studies conducted in the social and behavioral sciences (Collins, Onwuegbuzie, $\&$ Jiao, 2007). Also, in a Concurrent Design using Identical Samples, the qualitative and quantitative data are collected at approximately the same point in time (i.e., concurrently) such that the collection of one type of data (e.g., qualitative data) does not depend on the collection of the other type of data (e.g., quantitative data) (Onwuegbuzie \& Collins, 2007).

\section{Instruments and Procedure}

Doctoral students were interviewed in three focus groups to ascertain the role that coping strategies had in the context of learning statistics. This number of focus groups was chosen because data saturation has been found to occur with three to six focus groups (Krueger, 1994; Morgan, 1997). After participants were invited and gave consent, three focus group interviews were scheduled within a 2-week period of time. As researchers, we served as the moderator and assistant moderator of each focus group. Members of each focus group were asked five questions (cf. Appendix) and probes were used to gather more information. Each interview was audio-recorded 
and the moderator transcribed each interview. Focus Group $1(n=7)$ lasted 42.13 minutes, Focus Group $2(n=5)$ lasted 33 minutes, and Focus Group $3(n=6)$ was 46.11 minutes, yielding a mean focus group session of 40.41 minutes $(S D=6.72)$. Focus Groups 1 and 3 were conducted within an existing class and Focus Group 2 was conducted in a small conference room before the students' evening class. The moderator also was an instructor 6 months prior of the members of Focus Group 1 and 2. The assistant moderator was the current instructor for Focus Group 3. The number of participants in Focus Group 1 and Focus Group 3 was within the six to nine participants (Krueger, 2000), six to 10 participants (Langford, Schoenfeld, \& Izzo, 2002; Morgan, 1997), and six to 12 participants (Bernard, 1995; Johnson \& Christensen, 2010; Onwuegbuzie, Dickinson, Leech, \& Zoran, 2009, 2010) recommended in the literature, with Focus Group 2 containing one less participant than the optimal size.

At the conclusion of each focus group, participants completed and returned a demographic questionnaire and the Coping Strategies Inventory for Statistics (CSIS). The demographic questionnaire extracted information such as the following: gender, age, grade point average, number of research methodology courses previously taken, number of statistics courses previously taken, number of mathematics courses previously taken, and grade on their statistics course. The supplementing of interview data with information from quantitative instruments has been advocated by Onwuegbuzie and Frels (2011) as a means of enhancing interpretations by helping researchers better contextualize qualitative findings. The CSIS, developed by Jarrell and Burry (1989), is a 40-item, 10-point Likert-format instrument that assesses non-facilitative study coping strategies and examination-taking strategies of students enrolled in quantitative-based courses (e.g., statistics). This instrument comprises two scales. The first scale evaluates study coping strategies, whereas the second scale assesses examination-taking coping strategies. High scores on both scales indicate more adequate coping strategies. For the present study, the study coping strategies subscale and the examination-taking coping subscale both generated scores that had a classical theory alpha reliability coefficient of $.78(95 \% \mathrm{CI}=.60, .90)$.

For each of the two CSIS subscales, the possible scores range from "0" to "180," with a "0" indicating a complete lack of coping strategies and "180" indicating a very high level of coping strategies. According to the authors of the CSIS, a student with a score of "130" or higher on a subscale is able to cope well in that area. A score between "110" and "129" might indicate remediation in certain areas. Finally, a score below "110" is indicative of a need for training in the use of coping strategies (Jarrell \& Burry, 1989).

Further, in order to promote reflexivity, the students in the third focus group were given points towards their overall statistics course grade for maintaining a reflexive journal—or what Maxwell (2005) calls a researcher identity memo - the purpose of which is to help researchers examine their "goals, experiences, assumptions, feelings, and values as they relate to [their] research, and to discover what resources and potential concerns [their] identity and experience may create" ( $p$. 27). The responses from the reflexive journal were used to triangulate the focus group interview responses.

\section{Research Design}

The qualitative component was dominant, with the less-dominant quantitative component embedded (i.e., involving collection and analysis of coping and demographic data) within the qualitative component. As such, a qualitative-dominant mixed research design was used (Johnson, Onwuegbuzie, \& Turner, 2007). Using Leech and Onwuegbuzie's (2009) typology, this embedded qualitative phase represented a fully mixed concurrent dominant status-qualitative design, wherein the qualitative and quantitative components occur at approximately the same point in time, with the quantitative phase being given higher priority and mixing occurring within or across the data collection, analysis, and interpretation stages. The rationale for combining qualita- 
tive and quantitative approaches, based on Greene, Caracelli, and Graham's (1989) framework, was that of complementarity (i.e., use of quantitative and qualitative methods "to measure overlapping but also different facets of a phenomenon" (p. 258)), initiation (i.e., use of quantitative and qualitative methods "to uncover paradox and contradiction" (p. 258)), expansion (i.e., use of quantitative and qualitative methods to "extend the scope, breadth, and range of inquiry" (p. 269)), and triangulation (i.e., use of qualitative and quantitative methods to seek convergence of findings).

\section{Data Analysis}

\section{Qualitative analyses}

After each focus group interview was transcribed, we analyzed the transcripts using classical content analysis (Berelson, 1952; Leech \& Onwuegbuzie, 2007, 2008) and constant comparison analysis (Glaser \& Strauss, 1967). The locus of typology development was investigative, arising from the intellectual constructions of the researchers (Constas, 1992). The sources for naming codes and locus of typology (i.e., theme) development were literature (i.e., based on Ramirez et al.'s (2010) reframing of the EVM) and investigative (i.e., stemming from the intellectual constructions of the researchers (Constas, 1992)) within an iterative process involving both a priori and a posteriori coding. More specifically, abductive coding was used that involved an interactive process of deductive coding and inductive coding.

Further, the verification component of categorization was empirical (Constas, 1992). The extracted themes were compared to the quantitative information - namely, the CSIS scores and quantitative demographic information (e.g., number of prior mathematics courses) - to assess levels of triangulation. Because quantitative data were used as a validation technique, in addition to being empirical the verification component of categorization was technical (Constas, 1992). The verification approach was accomplished a posteriori (Constas, 1992).

Further, using Miles and Huberman's (1994) framework — as recommended by Onwuegbuzie, Dickinson, Leech, \& Zoran (2010) for analyzing focus group data - a series of within-case and cross-case analyses was conducted. With respect to the cross-case analyses, the following analyses were conducted: (a) case-ordered effects matrix (i.e., sorts participants by degrees of the major cause of interest and shows the diverse effects for each participant); (b) case-ordered predictor-outcome matrix (i.e., arranges participants with respect to a main outcome variable and provides data for each participants on the main antecedent variables); and (c) causal networks (i.e., comparative analysis of all participants using variables considered to be the most influential in explaining the outcome or criterion) (cf. Miles \& Huberman, 1994).

With respect to within-case analyses, the following analyses were conducted: (a) conceptually ordered displays (i.e., visual representations that are ordered by concepts or variables); (b) event listing (i.e., matrix or flowchart that organizes a series of specific events by chronological time periods and sorts them into two or more categories); (c) effects matrix (i.e., displays data yielding one or more outcomes in a differentiated manner, focusing on the outcome/dependent variable, namely statistics achievement); and (d) causal network (i.e., displays the most important independent and dependent variables and their inter-relationships) (cf. Miles \& Huberman, 1994).

\section{Unit of analysis}

Focus group researchers tend to treat the group — and not the individuals comprising the focus group(s) - as the primary unit of analysis (Morgan, 1997; Wilkinson, 1998). These researchers code the group-based data and then present the emergent themes. However, as noted by Onwuegbuzie et al. (2010), focusing only on data generated by the groups can be very problemat- 
ic because group-based data alone (a) provide no information about the degree of consensus and dissent, (b) provide no information about other focus group members who might not have contributed to the category or theme, and (c) make it difficult to determine the degree to which the data that contributed to the theme reached saturation for the focus group (i.e., within-group data saturation; Onwuegbuzie, Dickinson, et al., 2009). As such, in the present study, we conducted what Onwuegbuzie, Dickinson, et al. $(2009,2010)$ refer to as a micro-interlocutor analysis, which involves not only identifying and providing the most compelling statements made by focus group participants, but also providing information about how many members (or the proportion of members) contributed/did not contribute to each category or theme.

\section{Mixed analysis}

Each theme was quantitized (Tashakkori \& Teddlie, 1998). That is, if a student listed a characteristic that was categorized as falling under a particular theme, then a score of 1 would be given to the theme for the student response; a score of 0 would be given otherwise. This dichomotization led to the formation of an interrespondent matrix (i.e., Student $\times$ Theme Matrix) (Onwuegbuzie, 2003; Onwuegbuzie \& Teddlie, 2003), which consisted only of 0s and 1s. A second interrespondent matrix was constructed that contained the frequency count indicating the number of times each theme was represented by each student. These matrices were used to compute both the frequency of each theme and the number of students who contributed to each theme.

Finally, as recommended by Onwuegbuzie et al. (2010), the themes extracted from the interviews were subjected to a correspondence analysis to compare and to contrast the themes that emerged from each of the three groups as a means of assessing the potential effect on the interview responses of students in Focus Group 3 currently taking a statistics course taught by the assistant moderator. Correspondence analysis is a technique for conducting a mixed analysis of emergent themes (cf. Michailidis, 2007). We utilized the QDA Miner 4.0 software program (Provalis Research, 2011) to analyze the qualitative data as well as to conduct the correspondence analysis. Thus, our mixed analysis represented a form of crossover mixed analysis (Onwuegbuzie \& Combs, 2010) because data associated with one tradition (i.e., qualitative thematic analysis) was analyzed via another tradition (i.e., quantitative analysis, correspondence analysis).

\section{Results}

\section{Cross-Case Analysis}

\section{Attitudes toward statistics}

Across the three focus groups, the participants listed a total of 402 significant statements. This represented a mean of 22.33 significant statements per focus group member. Table 1 presents the themes that were extracted from the classical content analysis, the description of these themes and corresponding selected examples of significant statements as a function of Eccles and Wigfield's (2002) EVM constructs and Ramirez et al.'s (2010) attitude components pertaining to the doctoral students' attitudes toward statistics. From this table, it can be seen that all the EVM constructs and all of Ramirez et al.'s (2010) attitude components were represented by one or more themes. Table 1 reveals that the following 13 themes were extracted from the students' attitudes toward statistics: class anxiety, performance anxiety, enjoyment and satisfaction, self-concept of one's abilities, expects to learn, expects high achievement, expects future success, value, difficulty, interest, effort, previous achievement-related experiences, and student characteristics. These themes mapped onto 10 Eccles and Wigfield (2002) EVM constructs and all eight of Ramirez et al.'s (2010) attitude components. 
Relationships among Attitudes, Coping Strategies, and Achievement

Table 1. Emergent Themes, Corresponding Description of Themes, and Corresponding Selected Examples of Significant Statements as a Function of Eccles and Wigfield's (2002) ExpectancyValue Model (EVM) Constructs and Ramirez et al.'s (2010) Attitude Components Pertaining to the Doctoral Students' Attitudes Toward Statistics

\begin{tabular}{|c|c|c|c|c|}
\hline $\begin{array}{l}\text { Ramirez et } \\
\text { al.'s (2010) } \\
\text { Attitude Com- } \\
\text { ponent }\end{array}$ & EVM Construct & Theme & Description & Significant Statement \\
\hline \multirow[t]{3}{*}{ Affect } & $\begin{array}{l}\text { "Affective Reac- } \\
\text { tions" }\end{array}$ & Class Anxiety & $\begin{array}{l}\text { Anxious while } \\
\text { participating in } \\
\text { the statistics } \\
\text { class }\end{array}$ & $\begin{array}{l}\text { "Just felt like from } \\
\text { the minute we } \\
\text { walked into the room } \\
\text { we had to be ready } \\
\text { and listening be- } \\
\text { cause it goes so } \\
\text { fast." }\end{array}$ \\
\hline & & $\begin{array}{l}\text { Performance } \\
\text { Anxiety }\end{array}$ & $\begin{array}{l}\text { Anxious about } \\
\text { performance, } \\
\text { assessment, and } \\
\text { expectations from } \\
\text { self or others }\end{array}$ & $\begin{array}{l}\text { "I must be an idiot } \\
\text { since I don't know } \\
\text { how to do this, so } \\
\text { trying to balance } \\
\text { what we should be } \\
\text { as a graduate stu- } \\
\text { dents and maybe } \\
\text { what is asking too } \\
\text { much of us." }\end{array}$ \\
\hline & $\begin{array}{l}\text { "Enjoyment } \\
\text { Value" }\end{array}$ & $\begin{array}{l}\text { Enjoyment and } \\
\text { Satisfaction }\end{array}$ & $\begin{array}{l}\text { Student per- } \\
\text { ceives satisfac- } \\
\text { tion in success- } \\
\text { fully completing } \\
\text { the statistics } \\
\text { course }\end{array}$ & $\begin{array}{l}\text { "I did find that as a } \\
\text { result of taking that } \\
\text { class, when we have } \\
\text { been reading our } \\
\text { assignments, that I } \\
\text { understand what a } \\
\text { multi regression is. } \\
\text { And reading our as- } \\
\text { signment for today, } \\
\text { and I thought, yea, } \\
\text { ok, yea I get it." }\end{array}$ \\
\hline \multirow[t]{2}{*}{$\begin{array}{l}\text { Cognitive } \\
\text { Competence }\end{array}$} & $\begin{array}{l}\text { "Self-Concept } \\
\text { of One's Abili- } \\
\text { ties" }\end{array}$ & $\begin{array}{l}\text { Self-Concept of } \\
\text { One's Abilities }\end{array}$ & $\begin{array}{l}\text { Lack of confi- } \\
\text { dence in under- } \\
\text { standing about } \\
\text { statistics }\end{array}$ & $\begin{array}{l}\text { "I found myself using } \\
\text { words that I did not } \\
\text { what they really } \\
\text { meant." }\end{array}$ \\
\hline & $\begin{array}{l}\text { "Expectation of } \\
\text { Success" }\end{array}$ & Expects to Learn & $\begin{array}{l}\text { Student expects } \\
\text { to learn statistical } \\
\text { concepts }\end{array}$ & $\begin{array}{l}\text { "One thing for me in } \\
\text { the [statistics] class, } \\
\text { taking notes, that } \\
\text { was very stressful. I } \\
\text { was so worried that I } \\
\text { wasn't going to get } \\
\text { everything and when } \\
\text { I got the digital re- } \\
\text { corder, I didn't panic } \\
\text { if I missed some- } \\
\text { thing." }\end{array}$ \\
\hline
\end{tabular}




\begin{tabular}{|c|c|c|c|c|}
\hline $\begin{array}{l}\text { Ramirez et } \\
\text { al.'s (2010) } \\
\text { Attitude Com- } \\
\text { ponent }\end{array}$ & EVM Construct & Theme & Description & Significant Statement \\
\hline & & $\begin{array}{l}\text { Expects High } \\
\text { Achievement }\end{array}$ & $\begin{array}{l}\text { Student expects } \\
\text { to earn high } \\
\text { grades in the sta- } \\
\text { tistics course. }\end{array}$ & $\begin{array}{l}\text { "Some of it [student's } \\
\text { anxiety related to the } \\
\text { course] was due to } \\
\text { the pressure I put on } \\
\text { myself because I } \\
\text { wanted to make an } \\
\text { A, so I put a tremen- } \\
\text { dous amount of } \\
\text { pressure on myself } \\
\text { to do well because I } \\
\text { wanted to do well." }\end{array}$ \\
\hline & & $\begin{array}{l}\text { Expects Future } \\
\text { Success }\end{array}$ & $\begin{array}{l}\text { Student expects } \\
\text { to succeed in the } \\
\text { doctoral program }\end{array}$ & $\begin{array}{l}\text { "[l] just wanted to do } \\
\text { well and in the doc- } \\
\text { toral program and } \\
\text { knew at the end of } \\
\text { the semester we } \\
\text { were going to be re- } \\
\text { viewed [probationary } \\
\text { status review by fac- } \\
\text { ulty]." }\end{array}$ \\
\hline Value & $\begin{array}{l}\text { "Attainment } \\
\text { Value" and } \\
\text { "Utility Value" }\end{array}$ & Value & $\begin{array}{l}\text { Student believes } \\
\text { that having suc- } \\
\text { cess in the statis- } \\
\text { tics course is re- } \\
\text { lated to his/her } \\
\text { future goals. }\end{array}$ & $\begin{array}{l}\text { "I was thinking I am } \\
\text { going to do the best I } \\
\text { can [in the statistics } \\
\text { course], I am going } \\
\text { to pay attention and } \\
\text { start applying and } \\
\text { thinking what my } \\
\text { dissertation is going } \\
\text { to be like." }\end{array}$ \\
\hline Difficulty & $\begin{array}{l}\text { Perception } \\
\text { of:... "Task } \\
\text { Demands" }\end{array}$ & Difficulty & $\begin{array}{l}\text { Problems with } \\
\text { aspects of the } \\
\text { assignments }\end{array}$ & $\begin{array}{l}\text { "For me, it was the } \\
\text { writing. SPSS was } \\
\text { not hard. Writing was } \\
\text { hard." }\end{array}$ \\
\hline Interest & "Intrinsic Value" & Interest & $\begin{array}{l}\text { Student finds and } \\
\text { uses resources to } \\
\text { support his/her } \\
\text { learning of statis- } \\
\text { tics such as the } \\
\text { Internet, instruc- } \\
\text { tor contacts, and } \\
\text { outside reading }\end{array}$ & $\begin{array}{l}\text { "It was a lot of infor- } \\
\text { mation on the } \\
\text { PowerPoints, and a } \\
\text { lot of information to } \\
\text { absorb and I kept } \\
\text { thinking to myself } \\
\text { you need something } \\
\text { else. I need some- } \\
\text { thing else to supple- } \\
\text { ment this to get an } \\
\text { understanding of } \\
\text { what I am doing." }\end{array}$ \\
\hline
\end{tabular}




\begin{tabular}{|l|l|l|l|l|}
\hline $\begin{array}{l}\text { Ramirez et } \\
\text { al.'s (2010) } \\
\text { Attitude Com- } \\
\text { ponent }\end{array}$ & EVM Construct & Theme & Description & Significant Statement \\
\hline Effort & "Cost" & Effort & $\begin{array}{l}\text { Student expends } \\
\text { effort outside of } \\
\text { class to learn } \\
\text { statistics and } \\
\text { complete as- } \\
\text { signments }\end{array}$ & $\begin{array}{l}\text { "I would take these } \\
\text { things [statistics as- } \\
\text { signments] to work } \\
\text { and church. I was } \\
\text { literally in church and } \\
\text { people were looking } \\
\text { at me and I was like, } \\
\text { I gotta do this." }\end{array}$ \\
\hline $\begin{array}{l}\text { Previous } \\
\text { Achievement }\end{array}$ & $\begin{array}{l}\text { "Previous } \\
\text { Achievement- } \\
\text { Related Experi- } \\
\text { ences" and "In- } \\
\text { terpretations of } \\
\text { Experience" }\end{array}$ & $\begin{array}{l}\text { Achievement- } \\
\text { Related Experi- } \\
\text { ences }\end{array}$ & $\begin{array}{l}\text { Student believes } \\
\text { he/she has/does } \\
\text { not have the } \\
\text { necessary back- } \\
\text { ground to suc- } \\
\text { ceed in the statis- } \\
\text { tics course }\end{array}$ & $\begin{array}{l}\text { "I'd never taken a } \\
\text { statistics class be- } \\
\text { fore and I knew it } \\
\text { was one of my weak } \\
\text { areas." }\end{array}$ \\
\hline $\begin{array}{l}\text { Student } \\
\text { Characteristics }\end{array}$ & $\begin{array}{l}\text { "Stable Child } \\
\text { Characteristics" }\end{array}$ & $\begin{array}{l}\text { Student Charac- } \\
\text { teristics }\end{array}$ & $\begin{array}{l}\text { Problems balanc- } \\
\text { ing multiple re- } \\
\text { sponsibilities in } \\
\text { and out of the } \\
\text { class }\end{array}$ & $\begin{array}{l}\text { What got in my way } \\
\text { is that I had a whole } \\
\text { other life and you } \\
\text { needed to just have } \\
\text { a life for statistics; I } \\
\text { had a whole other } \\
\text { job, it was too much." }\end{array}$ \\
\hline
\end{tabular}

Table 2 presents the prevalence rates (Onwuegbuzie, 2003; Onwuegbuzie \& Teddlie, 2003) for each of the 13 themes, the 10 EVM constructs, and the eight attitude components. Interestingly, class anxiety and interest were the most endorsed themes, each with a prevalence rate of 54 . This was followed closely by performance anxiety (prevalence rate $=50$ ). The next most endorsed theme was self-concept of one's abilities (prevalence rate $=37$ ). These themes each represented very large effect sizes because they comprised more than two significant statements per focus group participant, on average. The next set of prevalence themes, respectively, were student characteristics (prevalence rate $=30$ ), effort (prevalence rate $=29$ ), and previous achievement-related experiences (prevalence rate $=23$ ). These themes represented large effect sizes, comprising more than one significant statement per focus group participant, on average. The following themes represented medium effect sizes because they each comprised between 0.5 and 1 significant statement per focus group participant, on average: difficulty (prevalence rate $=18$ ), enjoyment and satisfaction (prevalence rate $=16$ ), expects to learn (prevalence rate $=16$ ), expects future success (prevalence rate $=13$ ), and expects high achievement (prevalence rate $=10$ ). Finally, value represented a small effect size (prevalence rate $=2$ ).

With respect to the EVM constructs, the construct "affective reactions" was by far the most prevalent construct (prevalence rate $=104$ ), followed by "intrinsic value" (prevalence rate $=54$ ) and "expectation of success" (prevalence rate $=39$ ), "self-concept of one's ability" (prevalence rate = 37 ), "stable child characteristics" (prevalence rate $=30$ ), "cost" (prevalence rate $=29$ ), "previous achievement-related experiences" and "interpretations of experience" (prevalence rate $=23$ ), "perception of: "task demands" (prevalence rate $=18$ ), "enjoyment value" (prevalence rate $=16$ ), and "attainment value" and "utility value" (prevalence rate $=2$ ), respectively. With regard to Ramirez et al.'s (2010) attitude components, affect (prevalence rate $=120$ ) was by far the most 
prevalent attitude, followed by cognitive competence (prevalence rate $=76$ ), interest (prevalence rate $=54$ ), student characteristics (prevalence rate $=30$ ), effort (prevalence rate $=29$ ), previous achievement (prevalence rate $=23$ ), difficulty (prevalence rate $=18$ ), and value (prevalence rate $=$ 2), respectively.

Table 2. Prevalence Rates of each Theme as a Function of Eccles and Wigfield's (2002) Expectancy-Value Model (EVM) Constructs and Ramirez et al.'s (2010) Attitude Components Pertaining to the Doctoral Students' Attitudes Toward Statistics

\begin{tabular}{|c|c|c|c|c|}
\hline $\begin{array}{l}\text { Ramirez et } \\
\text { al.'s (2010) } \\
\text { Attitude Com- } \\
\text { ponent }\end{array}$ & EVM Construct & Theme & Prevalence Rate & $\begin{array}{l}\text { Number of Stu- } \\
\text { dents Endorsing } \\
\text { the Theme } \\
(\text { Total }=18 \text { ) }\end{array}$ \\
\hline \multirow[t]{4}{*}{ Affect } & & & 120 & 18 \\
\hline & $\begin{array}{l}\text { "Affective Reac- } \\
\text { tions" }\end{array}$ & Class Anxiety & 54 & 18 \\
\hline & & $\begin{array}{l}\text { Performance Anx- } \\
\text { iety }\end{array}$ & 50 & 17 \\
\hline & $\begin{array}{l}\text { "Enjoyment } \\
\text { Value" }\end{array}$ & $\begin{array}{l}\text { Enjoyment and } \\
\text { Satisfaction }\end{array}$ & 16 & 9 \\
\hline \multirow[t]{5}{*}{$\begin{array}{l}\text { Cognitive } \\
\text { Competence }\end{array}$} & & & 76 & 18 \\
\hline & $\begin{array}{l}\text { "Self-Concept of } \\
\text { One's Abilities" }\end{array}$ & $\begin{array}{l}\text { Self-Concept of } \\
\text { One's Abilities }\end{array}$ & 37 & 15 \\
\hline & $\begin{array}{l}\text { "Expectation of } \\
\text { Success" }\end{array}$ & Expects to Learn & 16 & 9 \\
\hline & & $\begin{array}{l}\text { Expects High } \\
\text { Achievement }\end{array}$ & 10 & 6 \\
\hline & & $\begin{array}{l}\text { Expects Future } \\
\text { Success }\end{array}$ & 13 & 8 \\
\hline Value & $\begin{array}{l}\text { "Attainment } \\
\text { Value" and "Util- } \\
\text { ity Value" }\end{array}$ & Value & 2 & 1 \\
\hline Difficulty & $\begin{array}{l}\text { Perception of:... } \\
\text { "Task De- } \\
\text { mands" }\end{array}$ & Difficulty & 18 & 11 \\
\hline Interest & "Intrinsic Value" & Interest & 54 & 17 \\
\hline Effort & "Cost" & Effort & 29 & 12 \\
\hline $\begin{array}{l}\text { Previous } \\
\text { Achievement }\end{array}$ & $\begin{array}{l}\text { "Previous } \\
\text { Achievement- } \\
\text { Related Experi- } \\
\text { ences" and "In- } \\
\text { terpretations of } \\
\text { Experience" }\end{array}$ & $\begin{array}{l}\text { Previous } \\
\text { Achievement- } \\
\text { Related Experi- } \\
\text { ences }\end{array}$ & 23 & 14 \\
\hline $\begin{array}{l}\text { Student } \\
\text { Characteristics }\end{array}$ & $\begin{array}{l}\text { "Stable Child } \\
\text { Characteristics" }\end{array}$ & $\begin{array}{l}\text { Student Charac- } \\
\text { teristics }\end{array}$ & 30 & 11 \\
\hline
\end{tabular}


Table 2 also provides information regarding the level of consensus pertaining to each theme, EVM construct, and statistic attitude. Most notably, all 18 participants provided one or more significant statements that were classified as representing class anxiety. Also, 17 of the students provided one or more significant statements that were classified as representing performance anxiety and intrinsic value. In fact, with the exception of the value theme (i.e., the "attainment value" and "utility value" and the value attitude), for which only one participant contributed a significant statement, all the themes, constructs, and attitudes were represented by at least one third of the participants.

A series of case-ordered effects matrices revealed some patterns between selected demographic variables and the students' contribution to the EVM. Most notably, some ethnicity differences were revealed. Interestingly, all five non-White participants lay in the center of the distribution with respect to their contribution to the EVM model. In particular, these non-White participants were much more likely to report high levels of performance anxiety than any other theme. These students also were relatively more likely to report effort and interest than the other themes, constructs, or other attitude components. Further, a pattern emerged between the number of previous college-level statistics courses taken and the contribution to the EVM. In particular, students who had taken the most college-level statistics courses tended to contribute more to the model than did the other students. Finally, patterns emerged between age and the students' contribution to the EVM. For example, the youngest students were much less likely to express any issues associated with the task demands such as problems associated with writing statistical reports.

\section{Coping strategies}

Table 3 presents the means and standard deviations pertaining to the two subscales of the CSIS. Interestingly, the subscale scores of the majority of participants (i.e., $n=13 ; 72.2 \%$ ) suggested that they were able to cope well in the area of examination-taking coping strategies. A further $16.7 \%(n=3)$ of students were classified as possibly needing remediation in certain areas of examination-taking coping strategies. Only two students (11.1\%) were classified as definitely needing training in the use of examination-taking coping strategies. For study coping strategies, $44.4 \%$ $(n=8)$ of the embedded qualitative sample members were classified as being able to cope well, $33.3 \%(n=6)$ were classified as possibly needing remediation in certain areas of study coping strategies, and $22.2 \%(n=4)$ were classified as definitely needing training in the use of study coping strategies. Interestingly, no statistically significant relationship emerged between the participants' classification of examination-taking coping strategies and their classification of study coping strategies $\left(X^{2}[4]=6.97, p=.14\right)$. This finding suggests that students who reported low coping strategies associated with examination-taking coping strategies did not necessarily report low coping strategies associated with study coping strategies.

Table 3. Means and Standard Deviations for the Subscales of the Coping Strategies Inventory for Statistics

\begin{tabular}{lcl}
\hline \multicolumn{1}{c}{ Dimension } & $M$ & $S D$ \\
\hline Examination-taking Coping Strategies & 135.17 & 20.77 \\
Study Coping Strategies & 124.06 & 20.88 \\
\hline
\end{tabular}

Table 4 presents a description of emergent themes for coping strategies used by the 18 participants. It can be seen from this table that the following five themes emerged: peer support, instructor support, personal management, class structure, and study skills. Each of these themes is described in the table, alongside exemplar significant statements. 
Table 4. Description of Emergent Themes for Coping Strategies Used in Statistics Course

\begin{tabular}{|c|c|c|}
\hline Theme & Description & Significant Statement Examples \\
\hline Peer support & $\begin{array}{l}\text { Asks for and receives } \\
\text { help from other peers } \\
\text { and collaborates with } \\
\text { others }\end{array}$ & $\begin{array}{l}\text { "For me, one of the biggest ad- } \\
\text { vantages I saw right then was being } \\
\text { in the cohort because you really } \\
\text { utilized that cohort, I could call Are- } \\
\text { tha, and another student, you } \\
\text { emailed all the time, you really got } \\
\text { to work well with everybody." }\end{array}$ \\
\hline Instructor support & $\begin{array}{l}\text { Asks for and receives } \\
\text { help from the instructor }\end{array}$ & $\begin{array}{l}\text { "He was very accessible I thought } \\
\text { outside of class which was helpful } \\
\text { because as those questions come } \\
\text { up, you'd shoot him an email and } \\
\text { within hours or a day you'd have a } \\
\text { response." }\end{array}$ \\
\hline Personal management & $\begin{array}{l}\text { Manages self with organ- } \\
\text { izational tools, routines, } \\
\text { and self-care }\end{array}$ & $\begin{array}{l}\text { "Taking notes, that was very stress- } \\
\text { ful. I was so worried that I wasn't } \\
\text { going to get everything and when I } \\
\text { got the digital recorder, I didn't pan- } \\
\text { ic if I missed something." }\end{array}$ \\
\hline Class structure & $\begin{array}{l}\text { Utilizes the resources } \\
\text { provided in the course }\end{array}$ & $\begin{array}{l}\text { "The way the course was presented } \\
\text { is we had an example paper, we } \\
\text { had a step by step routine in how to } \\
\text { do it, and um an assignment page." }\end{array}$ \\
\hline Study skills & $\begin{array}{l}\text { Applies skills such as } \\
\text { listening, correcting er- } \\
\text { rors, and seeking addi- } \\
\text { tional resources }\end{array}$ & $\begin{array}{l}\text { "I would try to go back and see the } \\
\text { errors I had made on the papers, } \\
\text { what were those words that weren't } \\
\text { supposed to be used." }\end{array}$ \\
\hline
\end{tabular}

Table 5 presents the prevalence rates for each of the five coping strategies themes. Interestingly, peer support was the most endorsed theme (prevalence rate $=41$ ), followed very closely by instructor support (prevalence rate $=40$ ) and personal management (prevalence rate $=40$ ). These themes each represented very large effect sizes because they comprised more than two significant statements per focus group participant, on average. The next set of prevalence themes, respectively, was class structure (prevalence rate $=10$ ) and study skills (prevalence rate $=11$ ) representing medium effect sizes. Table 5 also provides information regarding the level of consensus pertaining to each theme. Most notably, all 18 participants provided one or more significant statements that were classified as representing personal management. Also, 17 of the students provided one or more significant statements that were classified as representing peer support. In fact, all five themes were represented by at least $44 \%$ of the participants. 
Table 5. Prevalence Rates of Each Emergent Theme Pertaining to the Doctoral Students' Coping Strategies Used in Statistics Courses

\begin{tabular}{lcc}
\hline \multicolumn{1}{c}{ Theme } & Prevalence Rate & $\begin{array}{c}\text { Number of Students } \\
\text { Endorsing the Theme } \\
\text { (Total = 18) }\end{array}$ \\
\hline Peer Support & 41 & 17 \\
Instructor Support & 40 & 12 \\
Personal Management & 40 & 18 \\
Class Structure & 10 & 8 \\
Study Skills & 11 & 8 \\
\hline
\end{tabular}

Table 6 presents the relationships between statistics achievement and each of the five emergent theme pertaining to the doctoral students' coping strategies used in statistics courses. Because of the small sample size (i.e., $n=18$ ), these correlations were not tested for statistical significance. However, they were assessed for practical significance using Cohen's (1988) criteria for evaluating the size of correlation coefficients. Using Cohen's criteria, it can be seen that all the correlations represented at least a small effect size, with the correlation between the class structure coping theme and statistics achievement representing a moderate effect size. This latter correlation suggests that students who utilized the resources provided in the course tended to have higher levels of statistics achievement.

Table 6. Relationships between Statistics Achievement and Each Emergent Theme Pertaining to the Doctoral Students' Coping Strategies Used in Statistics Courses

\begin{tabular}{ll}
\hline \multicolumn{1}{c}{ Theme } & $\mathrm{r}_{\mathrm{s}}{ }^{\mathrm{a}}$ \\
\hline Peer Support & $.16^{\mathrm{b}}$ \\
Instructor Support & $.16^{\mathrm{b}}$ \\
Personal Management & $.16^{\mathrm{b}}$ \\
Class Structure & $.29^{\mathrm{c}}$ \\
Study Skills & $.15^{\mathrm{b}}$ \\
\hline
\end{tabular}

${ }^{a} r_{s}$ denotes Spearman's rho.

b_Correlation represents a small relationship using Cohen's (1988) criteria.

' _Correlation represents a moderate relationship using Cohen's (1988) criteria.

With respect to the scores on the two subscales of the CSIS, the correlation between statistics achievement and examination-taking coping strategies represented a small effect size $\left(r_{s}=.10\right)$, whereas the correlation between statistics achievement and study coping strategies represented a small effect size $\left(r_{s}=.31\right)$. Thus, study coping strategies were a better predictor of statistics achievement than were examination-taking coping strategies. Moreover, the correlations between statistics achievement and the six qualitative-based emergent themes (Table 6) and two quantitative-based measures of coping strategies suggest a link between coping and statistics achievement. 


\section{Mixed analysis}

A statistically significant relationship emerged between examination-taking coping strategies scores and the overall frequency of the five coping strategies themes, $r=.46, p<.05$. This relationship, which represented a large effect size (Cohen, 1988), indicated that students with high levels of coping strategies provided more coping strategies than did their counterparts. Further, although the relationship between the study coping strategies scores and the overall frequency of the five coping strategies themes was not statistically significant, $r=.34, p>.05$, because of the small sample size, the effect size associated with this relationship was notable, being in the moderate range (Cohen, 1988). Thus, the quantitative data (i.e., study coping strategies scores from the CSIS) validated (i.e., triangulated) the qualitative data (emergent coping strategies themes). Interestingly, after applying the Bonferroni adjustment to maintain a 5\% familywise error rate, professional support was statistically significantly related to examination-taking coping strategies scores, $r=.56, p=.01$, representing a large effect size.

Case-ordered matrices. A series of case-ordered effects matrices revealed gender differences in the coping strategies reported being used. In general, the male participants used fewer coping strategies than did the female participants. In particular, four of the five males were in the bottom half of the distribution with respect to the number of coping strategies reported, with two of the male participants reporting using the smallest number of strategies - however, these two participants reported using strategies that were classified as representing peer support and personal management strategies.

The case-ordered effects matrices also suggested ethnicity differences. Interestingly, all five nonWhite participants lay in the center of the distribution with respect to the number of coping strategies reported. For these participants, the most consistently used coping strategies were study skills and personal management, followed by peer support. Class structure represented the least reported coping strategy.

A pattern also emerged between the number of previous college-level mathematics courses taken and the number and type of coping strategies reported. In particular, the two students who had taken the highest number of college-level mathematics courses reported among the lowest number of coping strategies, for the most part, reporting using only peer support and personal management. In stark contrast, students who had taken the highest number of college-level statistics courses tended to report the highest number of coping strategies, with instructor support being by far the most dominant coping strategy reported.

A case-ordered predictor-outcome matrix also revealed some patterns between the coping strategies reported and their statistics achievement. Most notably, students who reported using the most strategies associated with peer support tended to attain the lowest levels of statistics achievement.

Finally, students who reported using the most strategies associated with class structure were more likely to attain the lowest levels of statistics achievement. The link between coping strategies used and statistics achievement was somewhat consistent with the relationship found between the students' study coping strategies, as measured by the CSIS, and their levels of statistics achievement, $r=.27$, which, although not statistically significant due to the small sample size, represented a moderate effect size (Cohen, 1988).

Causal Network Analysis. Based on the variables that were identified as being influential in the EVM, a causal network analysis (Miles \& Huberman, 1994) was conducted to outline how these variables might explain both the short-tem outcome (i.e., achievement in the statistics course) and the long-term outcome (e.g., completion of doctoral degree programs, presenting articles at professional meetings, securing the publication of articles). This yielded the causal network in Figure 
1, which we call the Expectancy-Value Coping Strategies (EVCS) model of statistics achievement. As can be seen from Figure 1, the EVCS model contains all the attitude components presented in Table 1 and all the coping strategies themes in Table 4, alongside the two CSIS dimensions, namely, study coping strategies and examination-taking coping strategies. The arrows in this figure indicate the hypothesized causal directions. Although cross-case analyses were used to conceptualize the EVCS model, as will be seen in the next section, within-case analyses were used to test and to explicate this model.

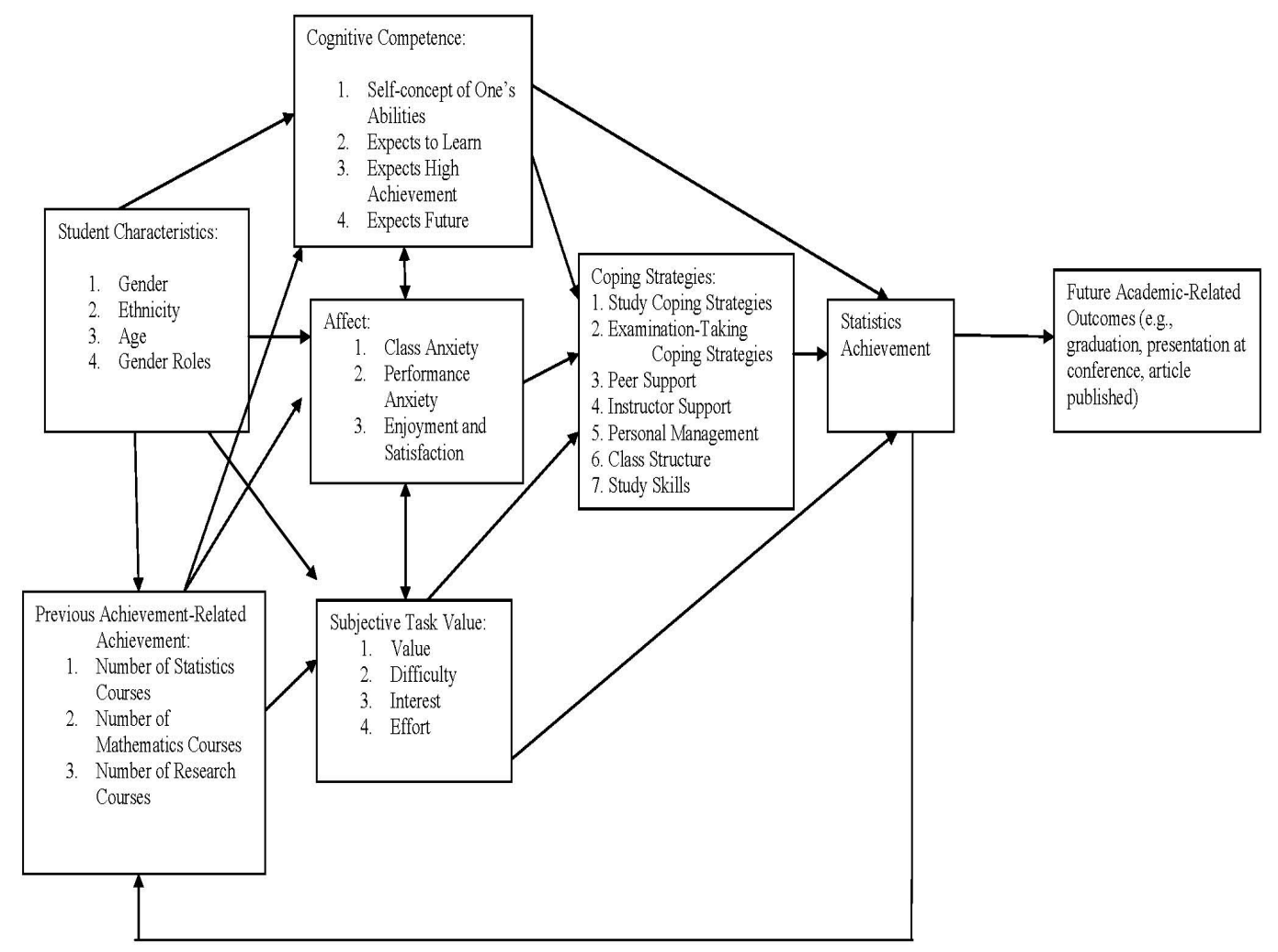

Figure 1. Hypothesized Expectancy-Value Coping Strategies Model of statistics achievement using the frameworks of Eccles and Wigfield (2002) and Ramirez et al. (2010), and based on the current data.

\section{Within-case Analysis}

Every participant provided statements during the focus group interviews. Following are two examples of doctoral students in the sample: one who indicated high levels of coping strategies and a high level of statistics achievement level, and one who had low levels of coping strategies and a low level of statistics achievement. Their scores on the CSIS also are provided. For confidentiality purposes, pseudonyms are used.

\section{Abby}

Abby is a White woman in her early 30 s and represents the youngest student in the sample. She is employed as a school administrator in an elementary school with 8 years of experience in education. Previously, she had taken five courses toward her doctoral degree program and in the semester she had taken statistics; she had taken two other doctoral-level courses. In relation to research-based and mathematics courses, she had taken three mathematics courses and four re- 
search-based courses. The statistics course was the first course in statistics she had taken, likely due her age, thereby supporting the link between student characteristics and previous achievement in the EVCS model. She attained an "A" grade in the course.

Evidence of affect, cognitive competence, and subjective task performance. Abby stated that she "was extremely anxious going into the class because I had never had statistics before." In addition, she commented that she had experienced a "challenging summer with one of the professors [and]. . . that was the source of my anxiety." Abby reported "everyone was saying that this [statistics class] was going to be so hard and I wasn't real overjoyed with the one [research methods] we had in the summer [group laughter] so then it turns out I didn't feel that way." She also experienced anxiety about being on probationary status in the doctoral program pending the outcome of the courses completed in that semester, which was a standard practice for all students in the program; she shared, "we were going to be evaluated at the end, and I didn't know what that would entail." Notwithstanding, she provided evidence of both interest and effort, such as via the following statement, "I was very particular about when I got my work finished and I always did it the assignment on Thursday.... even though we had 2 weeks to do the assignment." Further, early in the interview, she declared that she "really enjoyed the class." Thus, it appears that most of Abby's anxiety was experienced prior to the course because she shared few comments about anxiety experienced during the course. In particular, she did not express any issues associated with the task demands such as problems associated with writing statistical reports, possibly because of her ethnicity and relatively young age, supporting the link among student characteristics and affect, cognitive competence, and subjective task performance in the EVCS model.

Coping strategies. On the CSIS, Abby had the second highest score, indicating high levels of coping in comparison to the participants. Abby's score on the study coping strategies and examination-taking coping strategies subscales placed her in the high coping strategies category. She had a mean $z$ score of 1.08 for the combined subscales, indicating that she was at least one standard deviation above the mean on coping strategies compared to the other students in this study.

Evidence of coping. Abby shared several strategies she used for coping with anxiety and being successful in the course. She stated, "I think what helped me the most is that I did email my papers to [name of student] every Thursday and again on Monday. . I loved being able to get the feedback from her." She shared that she "was so scared about doing well in the class" that she was "ultra organized" and worked ahead of the class schedule in order to ask for help from the instructor. "So that is how I did well, I did it early enough and had [name of instructor] look at everything, so it had nothing to do with me being good at statistics." Another strategy that she employed during the class was selective listening in that she took frequent restroom breaks during the statistics class:

"because I couldn't hear a lot of what [instructor] was saying, I feel like I understood it better. If I tried to listen to every single word said I would be lost, because [instructor] speaks so knowledgeably about the topic that I didn't know enough about it. So I was catching the key phrase or things [instructor] would repeat and would point to it and I would be like "oh!" . . I feel like I got a pretty good grasp of it."

The following statement provided evidence of the positive role that both class structure and personal management played in the statistics course: "I am very Type A personality, and I like my lists, and when he gave us the assignment sheet-here is what you do, step one, click here- I loved it!" Although she expressed some trepidation of contacting the statistics instructor, she reported asking for the instructor's help and expressed "I really liked our professor, [he/she] is really nice and funny, very responsive to us." Encouragingly, that Abby, who was the youngest participant, presented numerous coping strategies is consistent with the very large negative and sta- 
tistically significant relationship that emerged between age and examination-taking coping strategies, $r=.67, p=.002$.

The coping strategies that she reported to address negative affect provided support to the link between affect and coping strategies in the EVCS model. Some of the strategies that she used also provided evidence of value, interest, and/or effort, or they represented an attempt to address difficulties associated with learning statistics, thereby showing how subjective task value might drive coping strategies in the EVCS model. Also, her attempts to use coping strategies to maximize her performance in the class provided evidence of a link between cognitive competence and coping strategies in the EVCS model. The fact that Abby deemed many of her coping strategies to be effective, coupled with her "A" grade for the class, provided evidence of the link between coping strategies and statistics achievement in the EVCS model. Finally, her reference to her probationary status suggested that she deemed this course to be important for successfully negotiating this probationary period, thereby showing a positive relationship between statistics achievement and future academic-related outcomes in the EVCS model.

\section{Celia}

Celia is a Hispanic woman in her 40s who works in the field of education. She is employed as a school administrator in an elementary school and has 12 years of experience in education. In regards to courses related to statistics, she had taken two college-level research-based courses, two statistics courses, and four college-level mathematics courses. She attained a "C" grade in the present statistics course. Indeed, her overall course average was the lowest among the study participants.

Evidence of affect, cognitive competence, and subjective task performance. When asked about the statistic course, Celia stated "it was difficult material," it "has been the most difficult class I have ever taken," and "I never have had a class that was so stressful." This provided evidence of the role of affect. She commented that when she began the class, she "didn't know anything about stats." Another source of stress for Celia was her family; she indicated that it "was very difficult to maintain a balance at home and at school. I was gone so much; it was a lot of stress and caused a lot in my family." This provided evidence of the role that student characteristics in general and gender roles in particular play in the ECVS model. Celia indicated that the class was "accelerated and I am the type of person that I need to dissect things and learn it on my own" but "time was just not there for me to ... really internalize things." This statement provides evidence of both difficulty and effort - two components of subjective task value. She concluded by stating that she wanted to review the course materials "because I haven't internalized yet, I truly don't understand statistics." In the context of the ECVS model, this comment relates to cognitive competence in general and self-concept of one's abilities in particular. Another statement that could be placed in this category was the following: "I don't learn things very easily, but it is OK. Everybody is different." A dominant subjective task value construct was difficulty, as exemplified by the following statement: "I am sure with practice you get proficient, do you? But, I mean I don't write that way so it was hard." Thus, Celia's experience illustrated how student characteristics, previous achievement, cognitive competence, subjective task value, and affect are inter-related.

Coping Strategies. On the CSIS, Celia's study coping strategies score represented the second lowest, placing her in the low study coping strategies category. In contrast, on the examinationtaking coping strategies subscale, she indicated high coping strategies. Celia had the fourth lowest combined $z$ score, indicating low overall levels of coping in comparison to the participants. Her mean combined $z$-score of -0.75 indicated that she was three fourths of a standard deviation below the mean on coping strategies compared to the other students in this study. 
Evidence of coping. When asked about coping, Celia stated that she gave up family time and sleep. She reported feeling "very angry," and reported that "a lot of profanity helps me." A questionable coping strategy that Celia used was to write poems that were riddled with profanity: "Stress was reflected in my poetry. That is when I wrote those vulgar poems." In addition, she commented that "collaboration and pairing yourself up with a smart person" was helpful to her. In terms of her relationship with the instructor, she commented that the teacher made a comment that "offended some people." Although one half of the focus group members refuted her claim, she reported that the instructor said "if you can't write, you don't belong in a doctoral program." Although Celia commented that it offended others, it appeared that she had negative feelings about this comment when she stated that, as a teacher, "you can't tell kids you can't do that." Even so, she reported using the instructor as a resource and commented on the instructor's attentiveness and quick response time- " "you would email [instructor] and ask how does this sound and [instructor] would tell you." She also reported using outside resources that were recommended by the instructor: "one of the books [instructor] recommended, it was really good." Based on these comments, it appeared that Celia was afraid to ask the instructor for help.

Overall, Celia appeared to exhibit some poor coping strategies, such as using profanity and ruminating on statements made by the instructor, which triangulated the low quantitative coping strategies scores. This showed links between coping strategies and cognitive competence, subjective task value, and affect in the EVCS model. As noted earlier, these links also were exhibited by Abby. However, whereas for Abby coping strategies served as a positive mediator of statistics achievement, with the coping strategies used appearing to enhance course achievement, for Celia coping strategies served as a negative mediator of statistics achievement, with some of the coping strategies (e.g., excessive use of profanity; writing vulgar poems) not helping to enhance course achievement - with Celia obtaining the lowest level of course achievement. In fact, it is likely that writing using coping strategies such as writing "vulgar poems" meant that she expended less effort on the completing the course assignments. Finally, the fact that Celia did not make any reference to future academic-related outcomes supports the hypothesized positive relationship between statistics achievement and future academic-related outcomes in the EVCS model.

\section{Discussion}

The purpose of this mixed research study was twofold: (a) to build on Ramirez et al.'s (2010) work by testing the EVM as a viable framework for understanding the statistics learning context, and (b) to examine the role that coping strategies play within the EVM framework by exploring interrelationships among attitudes, coping strategies, and statistics achievement.

There were several threats to internal credibility of the findings ("the truth value, applicability, consistency, neutrality, dependability, and/or credibility of interpretations and conclusions within the underlying setting or group"; Onwuegbuzie \& Leech, 2007, p. 234). However, the biggest threats to the findings were descriptive validity (i.e., factual accuracy of the account; Maxwell, 1992, 2005) and interpretive validity (i.e., the extent that a researcher's interpretation of an account represents an understanding of the study participants' voice and the meanings that they attach to their words and actions; Maxwell, 1992, 2005). However, descriptive validity and interpretive validity were enhanced by the fact that much of the information was consistent with statements made in the reflexive journals. Also, because one of the researchers was a statistics instructor himself, he was able to provide an emic perspective alongside an etic perspective. Further, the fact that all the themes secured endorsement rates that mostly yielded at least moderate effect sizes suggests that data saturation took place.

Another threat to internal credibility stemmed from the fact that the third focus group contained students who currently were enrolled in a statistics course with one of the researchers, who served as an assistant moderator, which possibly yielded a confounding effect. In particular, it is possible 
that one or more of the students in the third focus group provided socially desirable responses in the presence of their statistics instructor. However, the correspondence analysis of the emergent themes did not indicate any group think. That is, the correspondence analysis did not reveal any pattern in the themes as a function of focus group.

Onwuegbuzie and Johnson (2006) identified nine legitimation types that pertain to mixed research. Each of these legitimation types is defined in Table 7, alongside an explanation of how each legitimation type was addressed in the current investigation. From this table, it can be seen that all nine threats were addressed to some degree. Nevertheless, despite the extremely rigorous nature of the mixed research design, replications of this investigation are needed to assess the transferability of these findings.

Table 7: Typology of Mixed Methods Legitimation Types

\begin{tabular}{|c|c|c|}
\hline Legitimation Type & Description & $\begin{array}{l}\text { How Legitimation Type was Enhanced in } \\
\text { Study }\end{array}$ \\
\hline $\begin{array}{l}\text { Sample } \\
\text { Integration }\end{array}$ & $\begin{array}{l}\text { The extent to which the relationship be- } \\
\text { tween the qualitative and quantitative } \\
\text { sampling designs yields quality meta- } \\
\text { inferences. }\end{array}$ & $\begin{array}{l}\text { Collecting both qualitative data (i.e., from the } \\
\text { interviews) and quantitative data (i.e., from } \\
\text { the quantitative instrument) from the same } \\
\text { group of participants }\end{array}$ \\
\hline Inside-Outside & $\begin{array}{l}\text { The extent to which the researcher accu- } \\
\text { rately presents and appropriately utilizes } \\
\text { both the insider's view and the observ- } \\
\text { er's views for purposes such as descrip- } \\
\text { tion and explanation. }\end{array}$ & $\begin{array}{l}\text { Capturing the participants' quantitative and } \\
\text { qualitative data (i.e., insiders' [emic] views) } \\
\text { and including an instructor of statistics cours- } \\
\text { es on the research team (observers' [etic] } \\
\text { views) }\end{array}$ \\
\hline $\begin{array}{l}\text { Weakness } \\
\text { Minimization }\end{array}$ & $\begin{array}{l}\text { The extent to which the weakness from } \\
\text { one approach is compensated by the } \\
\text { strengths from the other approach. }\end{array}$ & $\begin{array}{l}\text { Combining descriptive precision (i.e., stem- } \\
\text { ming from qualitative analyses) with empiri- } \\
\text { cal precision (i.e., stemming from quantita- } \\
\text { tive [i.e., descriptive and correspondence] } \\
\text { analyses) }\end{array}$ \\
\hline Sequential & $\begin{array}{l}\text { The extent to which one has minimized } \\
\text { the potential problem whereby the meta- } \\
\text { inferences could be affected by revers- } \\
\text { ing the sequence of the quantitative and } \\
\text { qualitative phases. }\end{array}$ & $\begin{array}{l}\text { Collecting quantitative and qualitative data } \\
\text { simultaneously (i.e., concurrently) }\end{array}$ \\
\hline Conversion & $\begin{array}{l}\text { The extent to which the quantitizing or } \\
\text { qualitizing yields quality meta-inferences. }\end{array}$ & $\begin{array}{l}\text { Obtaining verification of quantitative analyses } \\
\text { of themes (e.g., correspondence analysis) via } \\
\text { triangulation }\end{array}$ \\
\hline $\begin{array}{l}\text { Paradigmatic } \\
\text { mixing }\end{array}$ & $\begin{array}{l}\text { The extent to which the researcher's } \\
\text { epistemological, ontological, axiological, } \\
\text { methodological, and rhetorical beliefs } \\
\text { that underlie the quantitative and qualita- } \\
\text { tive approaches are successfully (a) } \\
\text { combined or (b) blended into a usable } \\
\text { package. }\end{array}$ & $\begin{array}{l}\text { Using a fully mixed research design (Leech \& } \\
\text { Onwuegbuzie, 2009), as well as by undergo- } \\
\text { ing all major steps of the mixed research } \\
\text { process }\end{array}$ \\
\hline $\begin{array}{l}\text { Commensurabil- } \\
\text { ity }\end{array}$ & $\begin{array}{l}\text { The extent to which the meta-inferences } \\
\text { made reflect a mixed worldview based } \\
\text { on the cognitive process of Gestalt } \\
\text { switching and integration. }\end{array}$ & $\begin{array}{l}\text { Using a team of researchers that was diverse } \\
\text { with respect to research training, research } \\
\text { experience, college teaching experience } \\
\text { (e.g., associate professor and full professor } \\
\text { titles were represented), and discipline (e.g., } \\
\text { educational leadership, research methodolo- } \\
\text { gist) }\end{array}$ \\
\hline
\end{tabular}




\begin{tabular}{|c|c|c|}
\hline Legitimation Type & Description & $\begin{array}{l}\text { How Legitimation Type was Enhanced in } \\
\text { Study }\end{array}$ \\
\hline Multiple Validities & $\begin{array}{l}\text { The extent to which addressing legitima- } \\
\text { tion of the quantitative and qualitative } \\
\text { components of the study result from the } \\
\text { use of quantitative, qualitative, and } \\
\text { mixed validity types, yielding high quality } \\
\text { meta-inferences. }\end{array}$ & $\begin{array}{l}\text { Using techniques (e.g., intercoder agreemen } \\
\text { triangulation, debriefing) that addressed as } \\
\text { many threats to the legitimation of both the } \\
\text { qualitative and quantitative findings as possi } \\
\text { ble }\end{array}$ \\
\hline Political & $\begin{array}{l}\text { The extent to which the consumers of } \\
\text { mixed methods research value the meta- } \\
\text { inferences stemming from both the } \\
\text { quantitative and qualitative components } \\
\text { of a study. }\end{array}$ & $\begin{array}{l}\text { Using rigorous qualitative and quantitative } \\
\text { techniques }\end{array}$ \\
\hline
\end{tabular}

Note. This table was adapted from Onwuegbuzie and Johnson (2006). Reprinted with kind permission of the Mid-South Educational Research Association and the Editors of Research in the Schools.

The qualitative and quantitative data provided strong support for the EVM, with the 13 extracted themes pertaining to the students' attitudes toward statistics mapping onto the 10 Eccles and Wigfield (2002) EVM constructs and all eight of Ramirez et al.'s (2010) attitude components. Further, the five emergent themes pertaining to coping strategies (i.e., peer support, instructor support, personal management, class structure, and study skills) support the contention (e.g., Jarrell \& Burry, 1989) that coping strategies represent a multidimensional construct. Interestingly, comparing Jarrell and Burry's (1989) two dimensions (i.e., study coping strategies and examination-taking coping strategies) to the five coping strategy themes that emerged reveals some similarities and some differences. Specifically, it appears that the emergent theme of study skills maps onto the study coping strategies dimension. However, the other four strategy themes did not map onto either to the study coping strategies and examination-taking coping strategies dimensions of CSIS. Thus, these four emergent themes (i.e., peer support, instructor support, personal management, class structure) should be the subject of further investigation.

The fact that all these EVM constructs and attitude components emerged in all three focus groups suggests that data saturation and informational redundancy was attained, that is, by the third focus group, no new or relevant information seemed to emerge pertaining to a category, and the category development was well-established and validated (Flick, 1998; Lincoln \& Guba, 1985; Morse, 1995; Strauss \& Corbin, 1990). This revelation provides support to researchers who contend that between three and six focus groups should be conducted (Krueger, 1994; Morgan, 1997) and that this number of focus groups allows the researcher to assess the extent to which saturation was achieved (Onwuegbuzie et al., 2010).

Most notably, the within-case analyses and cross-case analyses provided evidence that coping strategies mediated the relationship between statistics attitudes and achievement in statistics courses, thereby providing incremental validity for the EVCS model, which represents a transformation of the EVM from a problem-focused model to a solution-focused model.

The qualitative analyses revealed an array of coping strategies that are used by doctoral students - some appear to be effective and others less effective and even debilitative. The coping strategies that appeared to help students included peer support, asking for help, and positive selftalk. Those that appeared to be ineffective were having unreasonable expectations of oneself, telling oneself negative messages (e.g., I am an idiot), and withdrawing from the support of others. The ECVS model then can be used to help students determine appropriate coping strategies, depending on their student characteristics, previous levels of achievement, cognitive competence, subjective task value, and affect.

The next step in the process is to use quantitative techniques (e.g., structural equation modeling) to test further the EVM in general and the ECVS in particular. Further, this model could be compared 
to other models of statistics achievement such as the Onwuegbuzie's (2003) anxiety-expectation mediation model, wherein statistics anxiety and achievement expectation played a central role in mediating the relationship between statistics achievement and the following variables: research anxiety, study habits, course load, and the number of statistics courses taken. We recommend, as did Ramirez et al. (2010), that the SATSC be used to test the ECVS model because all six attitude components of the SATS (C) maps onto to EVM. The SATS(C) then could be supplemented by the CSIS because the former does not measure coping strategies, whereas the latter does. In addition, such a line of research might benefit from the development of a measure of coping strategies that incorporates all five coping strategies themes that emerged in the current investigation.

In addition, qualitative approaches can be used to explain further this model. For example, ethnomethodology could be used to study further coping strategies situated within the ECVS model. According to Garfinkel (2002), ethnomethodology involves the study of how individuals negotiate everyday interactions and produce social order (i.e., study of social action) and, thus, is very appropriate for studying the statistical learning context, which has a social context. Optimally, future studies are needed to explore the complex relationships among statistics attitudes, coping strategies, and statistics achievement using mixed research techniques such as those undertaken in the present study.

\section{Implications of the Findings}

Because the present study involves the use of a relatively small sample size, it is not justified for us to make external statistical generalizations (i.e., generalize the findings to the population of doctoral students; cf. Onwuegbuzie, Slate, Leech, \& Collins, 2009). Thus, instead of providing the practical implications of our findings for all doctoral students, we will provide practical implications for our sample of doctoral students and then rely on other doctoral students and faculty members (e.g., instructors of statistics courses, advisors/supervisors, mentors) to make generalizations entirely, or at least in part, from their personal or vicarious experiences (Stake \& Trumbull, 1982).

First, we recommend that all the instructors of statistics courses at the institution where the study took place should entertain the idea, as evidenced by our numerous findings, that the link between attitudes towards statistics and statistics achievement not only is correlational-as has been shown repeatedly in the extant literature (e.g., Schau, 2003) - but also it is a causal one, at least for the current sample of students. As such, we recommend that these instructors, on the first day of their statistics courses, should discuss with their students the pivotal role that attitudes play in the statistics context, with the set of attitudes serving as an affective filter in statistics courses, wherein negative attitudes toward statistics renders students unreceptive to learning of statistical concepts, which, in turn, decreases performance levels (cf. Krashen, 1980). We believe that any time that is lost in teaching statistical concepts on the first day of class (or at another time point, if needed) would be gained with interest to the extent that this discussion leads to more positive attitudes among the students.

Second, we recommend that these statistics instructors also consider requesting or even requiring for extra credit (as the second author of this article has undertaken for the last 18 years) that their students maintain a regular (e.g., weekly) reflexive journal documenting their attitudes towards their statistics course, as well as their experiences both within and outside the statistics classroom (cf. Onwuegbuzie et al., 1997). These reflexive journals have the potential benefit of not only sending a message to students that their instructors care about their affective needs, but also allow instructors to be cognizant of students' attitudes and experiences throughout the course and to make future evidence-based adjustments to their pedagogies as needed. Interestingly, many students have stated that they believed the writing of these reflexive journals to be therapeutic for them. 
Another strategy that these instructors might find useful for improving attitudes via increasing the students' interest (intrinsic value), value (utility), and effort (cost) is by encouraging students to present their statistical reports at student-friendly conferences such as the Southwest Educational Research Association (SERA) conference (http://sera-edresearch.org/), wherein more than 50\% of presenters are doctoral students. By mentoring numerous students over the last several years through the process of presenting at the SERA conference-from idea conceptualization to proposal writing to Institutional Review Board submission to data collection to data analysis to report writing to conference presentation - we have observed students transition from doctoral students to beginning researchers who expect future academic-related success using statistics as a tool. Other instructional strategies that students might consider using can be gleaned from the literature, including the following: using humor, applying statistics to real-world situations, and encouraging students to work in co-operative learning groups (for a review, see Onwuegbuzie \& Wilson, 2003).

With respect to the doctoral students in this study, instructors should consider making them aware that coping strategies mediate the relationship between statistics attitudes and achievement in statistics courses. In particular, it is essential for students to recognize the coping strategies that are facilitative (e.g., peer support, asking for help, and positive self-talk) and those that are debilitative (e.g., having unreasonable expectations of oneself, telling oneself negative messages, and withdrawing from the support of others). These students also should be encouraged to determine their optimal coping strategies using the ECVS model. Whatever coping strategies these students use, they should be encouraged to share their experiences with other class/cohort members so that they can deconstruct their own problems associated with the learning of statistical concepts and identify possible solutions - in line with the solution-focused goal of the ECVS.

\section{References}

Bandalos, D. L., Finney, S. J., \& Geske, J. A. (2003). A model of statistics performance based on achievement goal theory. Journal of Educational Psychology, 95, 604-616. doi:10.1037/0022-0663.95.3.604

Berelson, B. (1952). Content analysis in communicative research. New York, NY: Free Press.

Bernard, H. R. (1995). Research methods in anthropology: Qualitative and quantitative approaches. Walnut Creek, CA: AltaMira.

Butler, S. (1996). Child protection or professional self-preservation by the baby nurses? Public health nurses and child protection in Ireland. Social Science and Medicine, 43, 303-314. doi:10.1016/02779536(95)00378-9

Capraro, R. M., \& Thompson, B. (2008). The educational researcher defined: What will future researchers be trained to do? Journal of Educational Research, 101, 247-253. doi:10.3200/JOER.101.4.247-253

Cohen, J. (1988).Statistical power analysis for the behavioral sciences (2nd ed.). Hillsdale, NJ: Lawrence Erlbaum.

Collins, K. M. T., Onwuegbuzie, A. J., \& Jiao, Q. G. (2007). A mixed method investigation of mixed methods sampling designs in social and health science research. Journal of Mixed Methods Research, 1, 267-294. doi:10.1177/1558689807299526

Constas, M. A. (1992). Qualitative data analysis as a public event: The documentation of category development procedures. American Educational Research Journal, 29, 253-266. doi:10.3102/00028312029002253

DeVaney, T. A. (2010). Anxiety and attitude of graduate students in on-campus vs. online statistics courses. Journal of Statistics Education, 18, 1-15. Retrieved from www.amstat.org/publications/jse/v18n1/devaney.pdf 
Relationships among Attitudes, Coping Strategies, and Achievement

Duggleby, W. (2005). What about focus group interaction data? Qualitative Health Research, 15, 832-840. doi: $10.1177 / 1049732304273916$

Dusek, J. B. (1980). The development of test anxiety in children. In I. G. Sarason (Ed.), Test anxiety: Theo$r y$, research and applications (pp. 87-110). Hillsdale, NJ: Lawrence Erlbaum.

Eccles, J. S., \& Wigfield, A. (2002). Motivational beliefs, values, and goals. Annual Review of Psychology, 53, 109-132. doi:10.1146/annurev.psych.53.100901.135153

Fisch, R. (1971). Course evaluation, test anxiety, and final test results in a statistics course. Zeithschrift fur Entwicklung psychologie und padagogische Psychologie, 3, 212-228.

Flick, U. (1998). An introduction to qualitative research: Theory, method and applications. London, England: Sage.

Garfinkel, H. (2002). Ethnomethodology's program. New York, NY: Rowman and Littlefield.

Glaser, B. G., \& Strauss, A. L. (1967). The discovery of grounded theory: Strategies for qualitative research. Chicago, IL: Aldine.

Greene, J. C., Caracelli, V. J., \& Graham, W. F. (1989). Toward a conceptual framework for mixed-method evaluation designs. Educational Evaluation and Policy Analysis, 11, 255-274. doi:10.3102/01623737011003255

Jarrell, M. G., \& Burry, J. A. (1989, November). Coping Strategies Inventory for Statistics. Paper presented at the annual meeting of the Mid-South Educational Research Association, Little Rock, AR.

Johnson, R. B., \& Christensen, L. (2010). Educational research: Quantitative, qualitative, and mixed approaches (4th ed.). Thousand Oaks, CA: Sage.

Johnson, R. B., Onwuegbuzie, A. J., \& Turner, L. A. (2007). Toward a definition of mixed methods research. Journal of Mixed Methods Research, 1, 112-133. doi:10.1177/1558689806298224

Krashen, D. (1980). The input hypothesis. In J. E. Alatis (Ed.), Current issues in bilingual education: Georgetown University Round Table on Language and Linguistics (pp. 168-180).Washington, DC: Georgetown University Press.

Krueger, R. A. (1994). Focus groups: A practical guide for applied research (2nd ed.). Thousand Oaks, CA: Sage.

Krueger, R. A. (2000). Focus groups: A practical guide for applied research (3rd ed.). Thousand Oaks, CA: Sage.

Langford, B. E., Schoenfeld, G., \& Izzo, G. (2002). Nominal grouping sessions vs. focus groups. Qualitative Market Research, 5, 58-70.

Lazarus, R. S., \& Folkman, S. (1984). Stress, appraisal, and coping. New York, NY: Springer Verlag.

Leech, N. L., \& Goodwin, L. D. (2008). Building a methodological foundation: Doctoral-Level methods courses in colleges of education. Research in the Schools, 15(1), 1-8.

Leech, N. L., \& Onwuegbuzie, A. J. (2007). An array of qualitative data analysis tools: A call for qualitative data analysis triangulation. School Psychology Quarterly, 22, 557-584.

Leech, N. L., \& Onwuegbuzie, A. J. (2008). Qualitative data analysis: A compendium of techniques and a framework for selection for school psychology research and beyond. School Psychology Quarterly, 23, 587-604. doi:10.1037/1045-3830.22.4.557

Leech, N. L., \& Onwuegbuzie, A. J. (2009). A typology of mixed methods research designs. Quality \& Quantity: International Journal of Methodology, 43, 265-275. doi:10.1007/s11135-007-9105-3

Lincoln, Y. S., \& Guba, E. G. (1985). Naturalistic inquiry. Beverly Hills, CA: Sage.

Maxwell, J. A. (1992). Understanding and validity in qualitative research. Harvard Educational Review, 62, 279-299. 
Maxwell, J. A. (2005). Qualitative research design: An interactive approach (2nd ed.). Newbury Park, CA: Sage.

Michailidis, G. (2007). Correspondence analysis. In N. J. Salkind (Ed.), Encyclopedia of measurement and statistics (pp. 191-194). Thousand Oaks, CA: Sage.

Miles, M. B., \& Huberman, A. M. (1994). Qualitative data analysis: An expanded sourcebook (2nd ed.). Thousand Oaks, CA: Sage.

Morgan, D. L. (1988). Focus groups as qualitative research. Newbury Park, CA: Sage.

Morgan, D. L. (1997). Focus groups as qualitative research (2nd ed.). Qualitative Research Methods Series 16. Thousand Oaks, CA: Sage.

Morse, J. M. (1995). The significance of saturation. Qualitative Health Research, 5, 147-149. doi:10.1177/104973239500500201

Onwuegbuzie, A. J. (2000). Attitude toward statistics assessments. Assessment and Evaluation in Higher Education, 25, 321-339. doi:10.1080/713611437

Onwuegbuzie, A. J. (2003). Modeling statistics achievement among graduate students. Educational and Psychological Measurement, 63, 1020-1038. doi:10.1177/0013164402250989

Onwuegbuzie, A. J., \& Collins, K. M. T. (2007). A typology of mixed methods sampling designs in social science research. The Qualitative Report, 12, 281-316. Retrieved from http://www.nova.edu/ssss/QR/QR12-2/onwuegbuzie2.pdf

Onwuegbuzie, A. J., \& Combs, J. P. (2010). Emergent data analysis techniques in mixed methods research: A synthesis. In A. Tashakkori \& C. Teddlie (Eds.), Sage handbook of mixed methods in social and behavioral research (2nd ed., pp. 397-430). Thousand Oaks, CA: Sage.

Onwuegbuzie, A. J., \& Daley, C. E. (1996). The relative contributions of examination-taking coping strategies and study coping strategies to test anxiety: A concurrent analysis. Cognitive Therapy and Research, 20, 287-303. doi:10.1007/BF02229239

Onwuegbuzie, A. J., DaRos, D. A., \& Ryan, J. (1997). The components of statistics anxiety: A phenomenological study. Focus on Learning Problems in Mathematics, 19(4), 11-35. doi:10.1016/S07408188(97)90003-7

Onwuegbuzie, A. J., Dickinson, W. B., Leech, N. L., \& Zoran, A. G. (2009). Toward more rigor in focus group research: A new framework for collecting and analyzing focus group data. International Journal of Qualitative Methods, 8(3), 1-21.

Onwuegbuzie, A. J., Dickinson, W. B., Leech, N. L., \& Zoran, A. G. (2010). Toward more rigor in focus group research in stress and coping and beyond: A new mixed research framework for collecting and analyzing focus group data. In G. S. Gates, W. H. Gmelch, \& M. Wolverton (Series Eds.) \& K. M. T. Collins, A. J. Onwuegbuzie, \& Q. G. Jiao (Vol. Eds.), Toward a broader understanding of stress and coping: Mixed methods approaches (pp. 243-285). The Research on Stress and Coping in Education Series (Vol. 5). Charlotte, NC: Information Age Publishing.

Onwuegbuzie, A. J., \& Frels, R. K. (2011, June-July). The utility of administering quantitative instruments in qualitative studies. Paper presented at the International Mixed Methods Conference, Leeds, England.

Onwuegbuzie, A. J., \& Johnson, R. B. (2006). The validity issues in mixed research. Research in the Schools, 13(1), 48-63.

Onwuegbuzie, A. J., \& Leech, N. L. (2007). Validity and qualitative research: An oxymoron? Quality \& Quantity: International Journal of Methodology, 41, 233-249. doi:10.1007/s11135-006-9000-3

Onwuegbuzie, A. J., \& Seaman, M. (1995). The effect of time and anxiety on statistics achievement. Journal of Experimental Psychology, 63, 115-124. doi:10.1080/00220973.1995.9943816 
Relationships among Attitudes, Coping Strategies, and Achievement

Onwuegbuzie, A. J., Slate, J. R., Leech, N. L., \& Collins, K. M. T. (2009). Mixed data analysis: Advanced integration techniques. International Journal of Multiple Research Approaches, 3, 13-33. doi:10.5172/mra.455.3.1.13

Onwuegbuzie, A. J., \& Teddlie, C. (2003). A framework for analyzing data in mixed methods research. In A. Tashakkori \& C. Teddlie (Eds.), Handbook of mixed methods in social and behavioral research (pp. 351-383). Thousand Oaks, CA: Sage.

Onwuegbuzie, A. J., \& Wilson, V. A. (2003). Statistics anxiety: Nature, etiology, antecedents, effects, and treatments: A comprehensive review of the literature. Teaching in Higher Education, 8, 195-209. doi:10.1080/1356251032000052447

Perepiczka, M., Chandler, N., \& Becerra, M (2011). Relationship between graduate students' statistics selfefficacy, statistics anxiety, attitude toward statistics, and social support. The Professional Counselor: Research and Practice, 1, 99-108.

Peters, D. A. (1993). Improving quality requires consumer input: Using focus groups. Journal of Nursing Care Quality, 7, 34-41. doi:10.1097/00001786-199301000-00006

Provalis Research. (2011). QDA Miner 4.0. User's guide. Montreal, QC, Canada: Author.

Ramirez, C., Emmioglu, E., \& Schau, C. (2010). Understanding students' attitudes toward statistics: New perspectives using an expectancy-value model of motivation and the Survey of Attitudes Toward Statistics@. Section on Statistical Education - Joint Statistical Meetings, 830-837. Retrieved from http://www.evaluationandstatistics.com/JSM2010EVM.pdf

Schau, C. (2003). Students' attitudes: The 'other' important outcome in statistics education. Joint Statistical Meetings, San Francisco, CA. Retrieved from http://evaluationandstatistics.com/JSM2003.pdf

Schau, C., Stevens, J., Dauphinee, T. L., \& DelVecchio, A. (1995). The development and validation of the Survey of Attitudes Toward Statistics. Educational and Psychological Measurement, 55, 868-875. doi:10.1177/0013164495055005022

Sim, J., \& Snell, J. (1996). Focus groups in physiotherapy evaluation and research. Physiotherapy, 82, 189198. doi:10.1016/S0031-9406(05)66923-4

Stake, R. E., \& Trumbull, D. J. (1982). Naturalistic generalizations. Review Journal of Philosophy and Social Science, 7, 3-12.

Strauss, A., \& Corbin, J. (1990). Basics of qualitative research: Grounded theory procedures and techniques. Newbury Park, CA: Sage.

Suanpang, P., Petocz, P., \& Kalceff, W. (2004). Student attitudes to learning business statistics: Comparison of online and traditional methods. Educational Technology \& Society, 7(3), 9-20.

Tashakkori, A., \& Teddlie, C. (1998). Mixed methodology: Combining qualitative and quantitative approaches (Applied Social Research Methods Series, Vol. 46). Thousand Oaks, CA: Sage.

Tobias, S. (1980). Math anxiety: What you can do about it. Today's Education, 69, 26-29.

Tobias, S. (1985). Test anxiety: Interference, defective skills and cognitive capacity. Educational Psychologist, 3, 135-142. doi:10.1207/s15326985ep2003_3

Vanhoof, S., Kuppens, S., Castro Sotos, A. E., Verschaffel, L., \& Onghena, P. (2011). Measuring statistics attitudes: Structure of the Survey of Attitudes Toward Statistics (SATS-36). Statistics Education Research Journal, 10, 35-51. Retrieved from http://www.stat.auckland.ac.nz/ iase/serj/SERJ10(1)_Vanhoof.pdf

Vaughn, S., Schumm, J. S., \& Sinagub, J. (1996). Focus group interviews in education and psychology. Thousand Oaks, CA: Sage.

Wilkinson, S. (1998). Focus group in health research: Exploring the meanings of health and illness. Journal of Health Psychology, 3, 329-348. doi:10.1177/135910539800300304 
Xu, Y. J., Meyer, K. A., \& Morgan, D. D. (2009). A mixed-methods assessment of using an online commercial tutoring system to teach introductory statistics. Journal of Statistics Education, 17(2), 1-17.

\section{Appendix: Interview Questions}

\section{Talk about your experiences in your most recent statistics course.}

2. One thing that other researchers have examined is anxiety related to this course. Talk to me about how anxious you were in the course relative to other courses.

3. What were some of the sources of your anxieties?

4. How did it manifest itself? (i.e., physical symptoms)

5. How did you attempt to cope with the anxiety?

\section{Biographies}

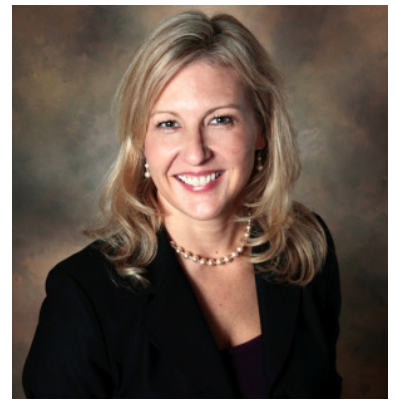

Julie P. Combs is Associate Professor in the Educational Leadership and Counseling department at Sam Houston State University. Previously, she worked as a school principal for 10 years at an awardwinning school. She teaches Academic Writing, Program Evaluation, and Re-search Methods courses in the doctoral program and various leadership courses in the principal certification program. In addition to maintaining an active research agenda focused on stress and coping, academic writing, and the role of the school principal, she has written over 30 journal articles, 6 book chapters, and co-authored two books, Managing Conflict: 50 Strategies for School Leaders and Examining What We Do to Improve Our Schools: Eight Steps from Analysis to Action. In addition, she has recently served as an associate editor of Educational Researcher.

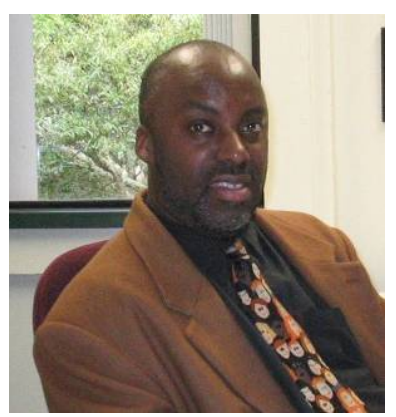

Anthony J. Onwuegbuzie is a tenured professor in the Department of Educational Leadership and Counseling at Sam Houston State University. He teaches doctoral-level courses in qualitative research, quantitative research, and mixed research. His research areas include disadvantaged and under-served populations such as minorities, juvenile delinquents, and children living in war zones. Additionally, he writes extensively on qualitative, quantitative, and mixed methodological topics. Alongside more than 650 conference/keynote presentations, he has had published more than 350 works, including more than 275 journal articles, 50 book chapters, and 2 books. His current h-index is 51 . He is former editor of Educational Researcher. He serves as co-editor of Research in the Schools. 